\title{
Finansal Krizler ve Asimetrik Enformasyon: Meksika ve Asya Krizleri'
}

Mehmet Mete KARADAĞ²

Makale Gönderim Tarihi: 31.01.2019

Makale Kabul Tarihi: 12.09.2019

\section{Öz}

Finansal piyasalarda asimetrik enformasyondan kaynaklanan sorunlar bu piyasaların etkin bir șekilde ișleyișine zarar vermekte; finansal piyasaların en verimli yatıım projelerine kaynak aktarımını gerçekleștirmesini engellemektedir. Gerek finansal gerekse finansal olmayan kurumların etkinliğini ve verimliliğini olumsuz yönde etkileyen asimetrik enformasyonun varlığı, ekonomik bașarısızlıkların ve finansal krizlerin de önemli faktörüdür.

Bu çalıșmada asimetrik enformasyon kavramı ele alınarak finansal krizlerdeki asimetrik enformasyon faktörü ve krizlerdeki rolü değerlendirilmekte, 1994 Meksika ve 1997 Asya krizleri asimetrik enformasyon açısından incelenmektedir.

Anahtar Kelimeler: Asimetrik enformasyon, ters seçim, ahlaki riziko, finansal krizler

JEL Kodları: G, G01, G21

\section{Financial Crises and Asymmetric Information: Mexican and Asian Crises}

\section{Abstract:}

The problems arising from asymmetric information in financial markets prevent the efficient functioning of these markets and prevent financial markets from transferring funds to the most efficient investment projects. The existence of asymmetric information, which negatively

1 Mehmet Mete KARADAĞ (2005), "Asimetrik Enformasyonun Bankacılık Sektörüne Etkileri: Türkiye Örneği", Marmara Üniversitesi, Yayımlanmamıș Doktora Tezi'nden türetilmiștir.

2 Dr. Öğr. Üyesi, İstanbul Aydın Üniversitesi, metekaradag@aydin.edu.tr, Orcid No: 000000001-8063-9151 
affects the efficiency and productivity of both financial and non-financial institutions, is an important factor in economic failures and financial crises.

In this study, the concept of asymmetric information will be discussed. Asymmetric information factor in financial crises and its role in crises will be evaluated. 1994 Mexico and 1997 Asian crises will be analyzed in terms of asymmetric information.

Keywords: Asymmetric information, adverse selection, moral hazard, financial crises

JEL Codes: G, G01, G21

\section{Giriș}

Tam enformasyon durumunda ișlem ve enformasyon maliyetleri sıfırdır ancak gerçekte piyasalarda bilgi tam değildir ve bazen elde edilebilmesi güçtür ayrıca, belirli bir maliyete katlanmayı gerektirmektedir. Taraflar arasında bilgi dağılımı eșit olmadığında, bilgi avantajına sahip olan taraflar bu avantajlarını diğerlerinin aleyhine kullanabilmektedir.

Asimetrik enformasyon problemi, piyasalarda yer alan tarafların birbirlerinden farklı enformasyon düzeylerine sahip olduğu bir durumu yansıtmaktadır. Asimetrik enformasyon "ters seçim" (adverse selection) ve "ahlaki riziko" (moral hazard) olmak üzere iki temel soruna yol açmaktadır. Ters seçim taraflar arasında sözleșme ya da ișlem öncesinde meydana gelmekte iken; ahlaki riziko ise sözleșme ya da ișlem sonrasında gerçekleșmektedir.

Enformasyon problemleri tek bir firma ya da piyasaya özgü problemler değildir. Neredeyse tüm piyasaların karșı karșıya oldukları problemlerdir. Asimetrik enformasyon farklı piyasalarda farklı biçimlerde görülebilmektedir. Sözgelimi, kullanılmıș bir otomobil satıcısı, otomobilin gerçek kalitesi hakkında potansiyel bir alıcıdan daha fazla bilgiye sahiptir; kredi piyasalarına göz attığımızda bankalar, kredi verirken borçlunun borcunu geriye ödeyebilme gücü hakkında borçlunun kendisinden daha az bilgiye sahiptir; sigorta șirketleri sigorta müșterilerinin gerçek risk durumları hakkında sigortalıdan daha az bilgiye sahiptir; emek piyasalarında ișe bașvuranlar gerçek nitelikleri hakkında ișverenden daha fazla bilgiye sahiptir ya da bir șirketin üst düzey yöneticileri, șirketin karlılık durumu hakkında hissedarlardan daha fazla bilgiye sahiptir. Bu tür örnekler daha da çoğaltılabilir. 
Finansal piyasalarda asimetrik enformasyondan kaynaklanan sorunlar finansal piyasaların ișleyișine zarar vererek finansal piyasaların verimli yatırım projelerine sahip ekonomik birimlere fon transferini gerçekleștirmesini engellemektedir. Bu durum sonucunda yatırımlarda azalma ve ekonomik faaliyetlerde büyük ölçekli daralmalar yașanabilmektedir. Asimetrik enformasyon, gerek finansal gerekse finansal olmayan kurumların verimliliğini ve etkinliğini olumsuz yönde etkilemektedir. Bu açılardan bakıldığında asimetrik enformasyonun varlığı, ekonomik bașarısızlıkların ve krizlerin de önemli bir faktörüdür.

Bu çalıșmada finansal krizlerdeki asimetrik enformasyon faktörü ele alınmakta, Meksika ve Asya krizleri bu bağlamda incelenmektedir.

Çalıșmada ilk olarak finansal piyasalarda asimetrik bilgi kavra$\mathrm{mı}$, finansal piyasalarda ters seçim ve ahlaki riziko problemleri açıklanmakta; izleyen așamalarda kriz tanımları, krizlerin nedenleri ve krizlerin asimetrik enformasyon görüșü ele alınmakta; son așamada ise sırası ile Meksika ve Asya krizleri asimetrik enformasyon açısından değerlendirilmektedir.

\section{Finansal Sistem ve Asimetrik Enformasyon}

Bilgisayar ve telekomünikasyon teknolojisindeki ilerlemeler ișlem maliyetleri üzerinde büyük etkiye sahiptir. Bilgisayarların gelișmesi ve ucuz veri transferi, ișlem maliyetlerinde büyük düșüșlere yol açmıștır. Bu, yapılabilir ișlem sayısını artırarak ve finansal kurumların geçmiște pahalı olan yeni finansal ürün ve hizmetleri sunmasını mümkün kılarak finansal sistemi daha etkin bir hale getirmiștir ve getirmeye de devam etmektedir. Teknolojik ilerlemelerden kaynaklanan ișlem maliyetlerindeki hızlı düșüșler, finansal sistemin değișmesindeki ana faktördür. Ancak, ișlem maliyetleri finansal sistemin etkin bir biçimde çalıșmasına tek engel değildir. Finansal bir ișlemde bir tarafın doğru kararlar alabilmesi için diğer taraf hakkında yeterli bilgiye sahip olmadığı bir durum olan asimetrik enformasyonun varlığı da önemlidir. Enformasyon yetersizliği finansal sistemde iki tür soruna yol açmaktadır: ters seçim ve ahlaki riziko (Mishkin ve Strahan, 1999).

Finansal sistem ekonomide verimli yatırım olanağına sahip birimlere fon aktarımını gerçekleștirmektedir. Eğer finansal sistem bu ișlevini yerine getiremezse ekonomi verimli șekilde ișleyemez. Finansal piyasalar iyi bir biçimde ișlediğinde herhangi bir sorun yoktur ancak ișlem ve asimetrik enformasyon problemleri finansal piyasaların etkin bir biçimde 
ișlemesini engellemekte ve piyasalara yönelik birtakım müdahalelerin ve düzenlemelerin yapılmasını gerekli kılmaktadır.

\subsection{Finansal Piyasalarda Ters Seçim Problemleri}

Ters seçim, ișlem öncesinde gerçekleșen bir asimetrik enformasyon problemidir çünkü yüksek kredi riskine sahip düșük kaliteli borçlular, kredi almaya ya da en yüksek faiz oranını ödemeye en istekli olanlardır. Bu nedenle, en istenmeyen sonucu meydana getirecek olan taraflar en büyük ihtimalle seçileceklerdir. Ters seçim, kredilerin kötü kredi riskine sahip olanlara verilmesi olasılığını arttırabildiği için borç verenler piyasada iyi kredi riskine sahip olanlar olsa dahi, kredi vermemeye karar verebilirler. Bu netice, ilk kez Akerlof tarafından tasvir edilen klasik 'limonlar problemi' analizinin bir özelliğidir. Ters seçim problemlerini azaltmak, borç verenlerin iyi kredi risklerini kötülerinden ayırmasını gerektirmektedir (Mishkin, 2000).

Kredi piyasalarında ters seçim ve teșvik etkilerini analiz eden Stiglitz ve Weiss (1981), asimetrik enformasyonun ters seçim ve ahlaki riziko problemlerine neden olarak belirli koșullar altında artan kredi talebiyle karșı karșıya kalındığında borç verenlerin faiz oranlarını ya da teminatları arttırmalarının karlı olmayabileceğine ișaret etmektedir. Ters seçimin bulunduğu piyasalarda kredi tayınlaması olabilmektedir. Bir yatırımın riski hakkında banka gibi borç verenler, borç almak isteyenlerden daha az enformasyona sahip olduklarında kredi tayınlaması gerçekleșebilmektedir. Kredi tayınlaması durumunda kredi piyasalarında yüksek faiz ödemeye razı olsalar da borçluların bazıları krediye erișememektedirler.

\subsection{Finansal Piyasalarda Ahlaki Riziko Problemleri}

Ahlaki riziko; sözleșme ya da finansal ișlem sonrasında taraflardan birinin diğerinin aleyhine olacak șekilde faaliyette bulunması riski olarak tanımlanabilir (Karadağ ve Selimler, 2014). Ahlaki riziko, bir tarafın riske karșı korunduğunu bilerek ve yatırımın bașarısız olması durumunda diğer tarafların nihai maliyete katlanacağını bilerek yüksek riskli bir yatırıma dahil olması durumunda ortaya çıkmaktadır (Koh, The ve Tan 2016). Finansal piyasalarda ahlaki rizikonun gerçekleșmesinin nedeni borç alanların, borç verenlerin çıkarlarının aleyhine olacak șekilde riskli aktivitelere girișme doğrultusunda sahip oldukları teșviktir.

Ahlaki riziko ne zaman iki taraf arasındaki bir anlașma her iki tarafın teșvik yapısını değiștirirse ortaya çıkar. Borç verme durumunda 
banka ödünç verdiği fonların kullanımını yakın bir biçimde izleyemezse borçlu daha riskli üretim tekniklerini seçebilir. Eğer "batmayacak kadar büyük" (too big to fail) politikası ya da "son bașvuru mercii" varsa, borç veren tarafında da ahlaki riziko problemi ortaya çıkabilir (Heffernan, 1996).

Mevduat sigortasının varlığı da ahlaki riziko problemleri ortaya çıkarabilmektedir. Bu durumda müșteriler mevduatlarının güvence altında olduğu bilgisiyle mevduatlarını yatırdıkları bankaları izleme gereği duymazlar ve en yüksek faizi öneren bankalara mevduatlarını yatıırlar; bankalar da yüksek kazanç sağlama amacı ile normalden daha fazla riskli aktivitelere girișebilirler.

\section{Finansal Krizler}

\subsection{Kriz Tanımları}

Eichengreen ve Bordo (2002) krizleri para krizleri, bankacılık krizleri ve ikiz krizler olarak üç gruba; Ma ve Cheng (2003), Bordo ve Murshid (2000) ise finansal krizleri para ve bankacılık krizleri olarak iki gruba ayırmaktadır.

Finansal krizler genellikle bir döviz krizi, bir banka krizi ya da bu ikisinin bir birleșimine ișaret etmektedir.

Genellikle ödemeler dengesi ve döviz krizleri, para (currency) krizi olarak adlandırılmaktadır (Yay, Yay ve Yılmaz, 2001). Para krizleri döviz kurunda ani hareketleri ve sermaye akımlarında ani değișmeleri içerir (Caprio, 1998). Para krizlerinin bir para biriminin döviz değerine spekülatif bir saldırının, para biriminin devalüasyonuna lya da șiddetli bir değer kaybına) yol açı̆ı̆ı veya büyük miktarlarda uluslararası rezervler harcayarak veya faiz oranlarını hızla artırarak yetkilileri para birimini savunmaya zorladığı zaman gerçekleștiği söylenebilir (IMF, 1998a).

Bankacılık krizi, bankaların öz kaynaklarının tamamının veya bir kısmının kaybına neden olan finansal dalgalanma olarak açıklanabilir (Kale ve Eken, (2017). Lee, Posenau ve Stebunovs (2017) bankacılık krizlerini bankacılık sisteminde banka hücumları, bankacılık sisteminde kayıplar ve banka tasfiyeleri gibi önemli finansal sıkıntı ișaretlerinin olması ve bankacılık sistemindeki büyük ölçekli kayıplara yönelik geniș çaplı bankacılık politikası müdahale önlemlerinin olması șeklinde tanımlamaktadırlar. 
Bankacılık sistemindeki finansal sıkıntı, bankacılık sistemindeki bankaların önemli bir kesiminin yükümlüklerini yerine getiremez duruma düștüğü ancak faaliyette kaldığı durumdur. Bu sorun, açık ya da örtülü mevduat sigortası ile banka hücumlarının önlendiği gelișmekte olan ve geçiș ülkelerinde nispeten yaygındır (Caprio ve Klingebiel, 1996). Demirgüç-Kunt ve Detragiache (1997)'e göre, așağıdaki dört koșuldan en az birinin geçerli olduğunda sıkıntılı bir durum tam bir kriz olarak sınıflandırılabilir:

- Bankacılık sisteminde takipteki kredilerin toplam aktiflere oranının \%10'u așması;

- Kurtarma operasyonunun maliyetinin en azından GSYiH'nın \%2 si kadar olması;

- Olayın, bankaların geniș ölçekli bir devletleștirilmesini içermesi;

- Büyük kapsamlı banka hücumlarının gerçekleșmesi ya da hükümetler tarafından mevduat hesaplarının dondurulması, uzatılan banka tatil süreleri ya da geniș çaplı mevduat garantileri gibi acil durum tedbirlerinin uygulanması.

İkiz krizler para ve bankacılık krizlerinin aynı anda gerçekleștiği krizlerdir. Eichengreen ve Bordo (2002)'ya göre, bir olayın ikiz kriz olarak nitelendirilebilmesi için aynı yıl ya da ardıșık yıllarda para ve bankacılık krizlerinin her ikisi de gözlemlenmelidir.

Sistemik finansal krizler, piyasanın etkin biçimde ișlemesini bozarak reel ekonomi üzerinde büyük olumsuz etkileri olabilen potansiyel açıdan finansal piyasaların büyük ölçüde aksaması ya da bozulmasıdır (IMF, 1998a).

\subsection{Krizlerin Nedenleri}

Birçok finansal kurum, kısa vadeli borçlarla uzun vadeli yatırımları finanse etme eğilimindedir. Bu vade uyumsuzluğu onları ekonomik șoklara karșı savunmasız bırakmaktadır. Küçük bir șok bile finansal bir krize yol açarak sonuçta maliyetli varlık tasfiyelerine ve aktif fiyatlarında büyük düșüșlere neden olabilmektedir (Kirabaeva, 2010).

Bazı durumlarda finansal krizler makroekonomik istikrarsızlıklar ve ekonomik yapıdaki bozukluklardan kaynaklanmaktadır. Ancak ekonomik temelleri sağlam olan ülkeler dâhi krizlere maruz kalabilmektedirler. Finansal krizler gerek gelișmiș gerekse gelișmekte olan ülke ekonomileri 
üzerine büyük maliyetler yüklemekte, ülkelerin sosyal yapıları üzerinde de önemli tahribata yol açmakta ve vergi mükellefleri ağır finansal yüklerle karșı karșıya kalmaktadır.

1990'lardan önce yașanan krizler daha çok ödemeler dengesi ve dıș borç krizleri iken, 1970-85 arasındaki krizler içinde bankacılık krizlerinin sayısı azdır; 1980 ortalarından itibaren bankacılık krizleri artıp 1990'lardan itibaren de krizler ikiz bir yapı kazanmaktadır (Yay ve diğerleri, 2001).

Ekonomistler genellikle finansal krizlerin azalan yabancı rezervler, artan dıș borç, sermaye hesabı ve cari hesap açıkları, kamu mali açığı ve bunun gibi zayıf ekonomik temellerin bir sonucu olduğuna inanmaktadırlar. Finansal krizlere maruz kalan neredeyse tüm ülkeler, krizin gerçekleșmesinden önce, artan cari hesap açıkları ile karșı karșıya kalmıșlardır. Bu yüzden bu tür açıklar finansal krizlerin önemli bir faktörü olarak kabul edilmektedir (Ma, ve Cheng, 2003).

Finansal sektör bozuklukları, makroekonomik oynaklıkla birlikte birçok bankacılık krizinin ardında yatan faktördür. Genellikle bu bozulmalar, zayıf denetim ve düzenleyici politikalara sahip olan ya da hükümetin kredinin fiyatlandırması ya da tahsisine doğrudan müdahale ettiği ülkelerdeki hızlı finansal liberalizasyon ve yenilik zamanlarında ortaya çıkmaktadır (IMF, 1998a). Genel belirsizlik, asimetrik enformasyon, așırı kredi genișlemesinin neden olduğu spekülatif balonlar, bankacılık krizlerinin nedenleri arasında gösterilen çeșitli faktörler arasında yer almaktadır. Ayrıca birçok banka bașarısızlığı reform girișimlerinin ardından meydana geldiği için finansal liberalizasyon da banka bașarısızlıklarında vurgulanan bir faktördür. Aktif-pasif uyumsuzlukları, yetersiz çeșitlendirme, bağlantılı krediler ve sahtekarlık dahil olmak üzere çeșitli düzenleyici ve bankaya özgü yönetim faktörleri de krizlerin nedenleri arasındadır (Caprio ve Klingebiel, 1996).

Ters șoklar ekonomiye vurduğunda ve yabancı yatırımcılar, yerli bankaların çok riskli olduklarına karar verdiklerinde finansal panik ve ekonomik krizler ansızın gerçekleșebilmektedir. Bir bașka ifadeyle, yabancı yatırımcılar yerli bankaların güvenliğinden șüphe duymaya bașlar bașlamaz, gayrimenkul fiyatları, gayrimenkullerin piyasa değerinin bunların düșüș öncesi değerine dayalı olan kredileri artık daha fazla karșılayamadığı bir düzeye kadar düșer. Sonuç olarak firmalar ve bankalar iflas eder. Bankacılık ve dıș borç krizleri aniden meydana gelir (Kim ve Lee, 2002). 
Daha önce baskı altındaki finansal sistem liberalize edildiğinde bankalar yetersiz deneyim, kalifiye eleman ve teknoloji nedeniyle finansal aracılık hizmetlerini verimli bir biçimde yerine getiremezler. Sonuçta finansal aracılık maliyetleri artar. Yeni liberalize edilmiș bankaların portföyleri yeni rejimle artan reel faiz oranları ve kredilerin risklilik durumlarını değerlendiremediklerinden daha riskli bir hale gelir (Gruben ve McComb, 1997). Sermaye piyasası liberalizasyonu çok büyük yabancı sermaye girișine yol açar, sırasıyla gelir, tüketim ve aktif fiyatları artar. Bu aktif balonu, riskli projelere borç vermede bir patlamaya neden olur. Er ya da geç bankacılık sektörü pahasına aktif balonu patlar. $O$ zaman yabancı yatırımcıları paniğe ve paralarını derhal çekmeye sürükler. Bunu ise bankacılık krizleri ve ekonomik krizler takip eder (Kim ve Lee, 2002).

\subsection{Krizlerin Asimetrik Enformasyon Görüșü}

Diğer piyasalarda olduğu gibi finansal piyasalar da asimetrik enformasyon problemine maruzdurlar. Hermalin ve Rose (1999)'a göre tüm finansal sistemler temelde iki önemli ve yaygın olgudan etkilenmektedir: Birincisi, borçlular ve alacaklılar asimetrik enformasyonun sıkıntısını çekmektedirler. İkinci önemli eksiklik, borçluların, borç verenlerin düșük maliyetle tahsil edebileceği geri ödemeleri güvenilir biçimde yapmayı taahhüt edemezler. Borçlular taahhütlerinden geri dönmeyi seçebildikleri için, borç verenler geri ödenmeme riskine katlanırlar. Birlikte bu ihtilaflar da düșük düzeyde finansal aktiviteye, daha yüksek faiz oranlarına ve yatırım risklerinin yetersiz bir derecede yayılmasına yol açar. Buna uluslararası boyut da eklendiğinde her iki problem de artar. Bir ülkedeki yatırım fırsatları ve riskleri hakkında yabancı aracılar yerli aracılara nazaran daha az enformasyona sahip olduğu için finansal piyasalar uluslararası bir boyut kazandığında asimetrik enformasyon problemleri daha kötüleșecektir. Yabancı aracılar yerlilerle rekabet ederken yerli aracılar maliyet avantajına sahip olacaklardır. Ayrıca yerli aracılar yabancılara nazaran daha iyi oranlar sunabildiklerinden, yabancı aracllar yerli müșteriler tarafından borç elde etmede ikinci seçenek olarak görüleceklerdir. Bunun anlamı, yabancı aracıların daha iyi enformasyona sahip yerli aracılarca kredi verilmeyi reddedilen borçlulardan kaynaklanan ters seçim ile karșılașabilmeleridir. Bu ters seçimin anlamı yabancı borç verenlerin daha da fazla riske maruz kalmalarıdır (Hermalin ve Rose, 1999).

Diğer yandan, küreselleșmenin öz sermaye maliyeti üzerindeki etkisini ele alan Stulz (1991), küreselleșme ile özsermaye maliyetinin 
azaldığına ișaret etmektedir. Küreselleșme, sermaye tedarikçileri arasında rekabet yaratmakta ve bu da sermaye sunanlara gidecek rantları ve ișlem maliyetlerini azaltarak firmaların sermaye maliyetlerini azaltmaktadır (Stulz, 1991). Bu açıdan borç alanlar ve verenler arasındaki enformasyon asimetrisine odaklanan Hermalin ve Rose'un görüșünün aksine yönetici ve hissedarlar arasındaki enformasyon asimetrisinin olduğu hisse senetleri piyasasında odaklanan Stulz, bu problemin sermaye akımlarının liberalizasyonu ve küreselleșme yoluyla artması yerine, finansal piyasaların uluslararasılașması ile düzeltildiğine inanmaktadır. Finansal küreselleșme, yurtiçi piyasada daha fazla yabancı yönetici ve hissedarın faaliyette bulunacağı, yabancı piyasalarda yerli yönetici ve hissedarların daha yoğun faaliyette bulunacağı anlamına gelir. Ekonomik ajanların sayısı arttıkça rekabet de artacak ve yerli yöneticiler yönetimlerini iyileștirmeye zorlanacaktır. Sonuç olarak, genel olarak asimetrik enformasyon ve ișlem maliyetleri azaltılmıș olacaktır (Bustelo, Garcia ve Olivie, 1999).

Finansal krizlerin asimetrik enformasyon görüșüne göre finansal krizler, ters seçim ve ahlaki riziko problemlerinin çok daha kötüleștiği, bu yüzden finansal piyasaların fonları en verimli yatıım fırsatlarına sahip olanlara etkin bir biçimde aktaramadığı, finansal piyasalardaki bozulmalardır. Finansal krizler, finansal piyasaların yetersiz biçimde ișlemesine neden olarak ekonomik aktivitede șiddetli daralmaya yol açarlar (Mishkin, 1990). Finansal krizin gerçekleșmesi ile asimetrik enformasyon problemleri daha da kötü bir hal alır, ekonomik aktivite geriler ve ekonomik iyileșme süreci daha yavaș gerçekleșir.

Finansal aracı kurulușların finansal aracılıkla uğrașma yeteneklerindeki ve kredi vermelerindeki bir azalma, yatırım ve toplam ekonomik aktivitede doğrudan bir azalmaya yol açacaktır. Finansal sistemde șoklar ters seçim ve ahlaki riziko problemlerini daha kötüleștirdiğinde borç verme azalma eğiliminde olacaktır. Kredi yetersizliği bireylerin ve firmaların harcamalarını kısmalarına yol açarak ekonomik aktivitede șiddetli biçimde daralmaya neden olur. Dört faktör asimetrik enformasyon problemlerinde artıșa ve böylece finansal krizlere neden almaktadır: finansal sektör bilançolarının bozulması, faiz oranlarındaki yükselișler, belirsizlikteki artıșlar, aktif fiyatlarındaki değișmelerden dolayı finansal olmayan sektör bilançolarındaki bozulmalar (Hahm ve Mishkin, 2000; Mishkin, 2001a; Mishkin, 2001b): 
- Finansal Sektör Bilançolarında Bozulma: Finansal aracıların bilançolarındaki bozulma, onların borç verme olanaklarını engeller ve bu yüzden finansal krizlere yol açan ana faktörlerden biridir. Eğer bankaların bilançolarındaki bozulma yeterince șiddetli ise, çoklu eșzamanlı bankacılık kurulușları bașarısızlığının olduğu banka paniklerine de yol açabilir. Gerçekten de, bir kamu güvenlik ağının yokluğunda sağlıklı bir bakanın bile bașarısız olmasına neden olan, bir banka bașarısızlığının diğerine sıçrayabildiği bir bulașma riski vardır. Bulașmanın kaynağı yine asimetrik enformasyondur. Bir panikte, mevduatlarının güvenliğinden endișe duyan ve bankanın kredi porfföyünün kalitesi konusunda bilgisiz olan mevduat sahipleri mevduatlarını banka sisteminden çekecekler bu da kredilerde bir daralmaya ve mevduatlarda çoklu bir daralmaya yol açacak ve diğer bankaların da bașarısız olmasına neden olacaktır. Bir bankanın iflası, bankanın katıldığı enformasyon ilișkisinde bir kayıp demektir ve bu yüzden bankacılık sektörü tarafından yapılabilecek finansal aracılık miktarında doğrudan bir kayıp anlamına gelmektedir. Sonuç ise verimli yatırımlara katkıda bulunan borç vermede daha șiddetli bir gerileme ve ekonomik aktivitede daha fazla daralmadır. Eğer bankaların bilançolarındaki bozulma șiddetli ise bankalar bașarısız olmaya bașlarlar ve korku sağlıklı bankaları da kapsayacak șekilde bir bankadan diğerine sıçrar. Sonuç olan çoklu banka bașarısızlıkları banka panikleri olarak bilinmektedir. Bulașmanın kaynağı tekrar asimetrik enformasyondur. Finansal kriz esnasında bankanın borç vermesindeki azalıș, daha yüksek faiz oranlarına yol açacak șekilde, borçlanmak isteyenlere arz edilen fonları azaltır. Banka paniğinin sonucu, kredi piyasalarında ters seçim ve ahlaki riziko problemlerinin artmasıdır. Bu problemler, ekonomik faaliyetlerde daha da șiddetli daralmaya yol açacak șekilde verimli yatırımlara kaynak aktarılmasında daha fazla bir azalıșa neden olur.

- Faiz oranlarındaki artıș: Faiz oranlarındaki artıș neticesinde kötü riskli borçlular halen kredi taleplerini sürdürürken, iyi riskliler daha az borçlanmak isteyeceklerdir. Ters seçim problemlerindeki artıș nedeniyle kredi verenler kredi miktarını kısıllayabileceklerdir. Bu da ekonomik aktivitenin daralmasına ve verilen kredi miktarının azalmasına yol açacaktır.

- Belirsizlikteki artıș: Finansal piyasalarda belirsizlikte dikkate değer bir artıș, borç verenlerin iyi kredi risklerini kötülerinden ayırmasını zorlaștırır. Borç verenlerin ters seçim ve ahlaki riziko problemlerini çözmedeki azalan yetenekleri onları borç vermeye daha az istekli duruma getirir, bu borç vermede, yatırım ve toplam aktivitede bir azalmaya yol açar. 
- Finansal olmayan bilançolarda bozulma: Eğer borçluların bilançolarında geniș çaplı bir bozulma varsa, finansal piyasalarda hem ters seçim hem de ahlaki riziko problemlerini kötüleștirerek finansal krizlerin gerçekleșmesine katkıda bulunur. Bu problem çok çeșitli yollarla ortaya çıkabilir. Örneğin, borç verenler asimetrik enformasyon problemlerini gidermek için teminattan yararlanırlar. Teminat, ters seçim veya ahlaki rizikonun olumsuz sonuçlarını azaltabilir, çünkü borç alanların yükümlülüklerini yerine getirememeleri durumunda borç verenler krediden kaynaklanan zararlarını telafi etmek için bu teminatları satabilirler. Fakat, eğer bir ekonomide aktif fiyatları ve de teminatın değeri düșerse, asimetrik enformasyon problemleri ansızın artar. Net değer de teminata benzer bir rol oynamaktadır. Eğer bir firma yüksek net değere sahipse firma borçlarını ödeyemese bile borç veren firmanın net değerinin tasarruf hakkını alarak onu satabilir ve bununla kayıplarının bir kısmını telafi edebilir. Yüksek net değer ayrıca borçlananların ahlaki rizikoya girișmeleri için teșviklerini de azaltmaktadır. Net değerin önemi, borsa çöküșlerinin neden finansal istikrarsızlığa yol açabildiğini açıklamaktadır. Net değeri azaltan borsa düșüșü borçluların ahlaki rizikoya girișmesi için teșvikleri arttırdığı için ve borç verenler de ters seçimin sonuçlarına karșı daha az korunduklarından dolayı verilen krediler azalır ve ekonomik faaliyetler geriler.

Faiz oranlarındaki artıșın, ters seçim problemlerinin artmasında doğrudan etkisi olmakla birlikte, faiz oranlarındaki artıș aynı zamanda firma ve hane halklarının bilançolarına etkisi yoluyla da finansal krizin ilerlemesinde rol oynar. Faiz oranlarındaki artıș ve bu yüzden hane halklarının ve firmaların faiz ödemelerindeki artıș firmanın nakit gelirleri ve nakit giderleri arasındaki fark olan nakit akımını azalıı. Nakit akımındaki azalma, bilançonun bozulmasına neden olur çünkü hane halkı ve firmaların likiditesini azalıı böylece borç verenlerin, firma ya da hane halkının faturalarını ödeyip ödeyemeyeceğini bilmesini zorlaștıır. Sonuç olarak ters seçim ve ahlaki riziko problemleri daha șiddetli olur ve borç verme ve ekonomik faaliyetlerde düșüș olur.

\subsubsection{Kamu Garantileri ve Kurtarmaları}

Bazı ekonomistler, kurtarma garantilerinin özel sektör tarafından alınan ekonomik kararları çarpıtan ve finansal krizleri kolaylaștıran hatta neden olan kötü bir politika olduğunu savunmaktadır. Özel sektöre gelecekteki krizlere karșı sigorta sağlayarak kurtarma garantileri ahlaki rizikoya neden olmaktadır. Piyasa katılımcıları isteyerek așırı risk almak- 
ta ve bu da așırı yatırımlara, çok fazla dıș borçlanmalara veya riskli dıș kredilere yol açmaktadır (Bems ve Jönsson, 2002). Kamu garantileri așırı bir seviyede gerçekleșirse ve süreklilik arz ederse piyasa katılımcılarının teșvik yapısını bozabilmektedir. Özellikle gelișmekte olan ülke piyasalarında vade uyumsuzluğu söz konusudur. Bu durum özellikle bankaları kırılgan ve krizlerden kolaylıkla etkilenebilir bir hale getirmektedir. Eğer yabancı yatıııcılar paniğe kapılıp fonlarını çekerlerse bankalar likidite sıkıntısına düșebilirler ve dolayısıyla yükümlülüklerini yerine getirmede zorlanabilirler. Hükümetler, güç duruma düșen bankaları kurtarma politikası izleyebilirler. Diğer yandan, kamu garantilerinin yokluğunda bir kriz esnasında kayba uğrayacağını bilen, kurtarılıp kurtarılmayacağından emin olmayan ekonomik birimler kararlarında daha basiretli davranacaklar ve borçlanırken daha dikkatli davranacaklardır.

\subsubsection{IMF ve Ahlaki Riziko}

Bazı yorumcular finansal krizler yașayan ülkelere uluslararası toplumun yardımının sadece borçluların, borç verenlerin ve yatırımcıların daha ihtiyatsız davranıșlarını yani ahlaki riziko olarak bilinen olguyu teșvik edeceğini savunmaktadırlar. IMF borç vermesi durumunda, ahlaki riziko hakkındaki endișeler, bu tür yardımın politika disiplinini zayıflatabilmesi ve yatırımcıların șayet yatırım kötü giderse bunun sonuçlarına sadece kısmi olarak katlanacakları inancı ile daha fazla risk almaları șeklindeki anlayıștan kaynaklanmaktadır. IMF kaynaklarının elde edilebilir olması potansiyel borç verenlerin ve borç alanların riskli davranıșlarını teșvik edebilmektedir. Karar alıcılar, șayet politikaları bașarısız olursa IMF'nin yanlarında olacağını bilerek daha riskli politikalar sürdürebilmektedir. Benzer șekilde borç verenler eğer ülke finansal bir sıkıntıya düșerse borçlarını ödemek için IMF kredisinin bir hükümete ya da onun bankalarına verileceğine inanıyorlarsa așırı risk alabilirler (IMF, 1998b). IMF'nin varlığı, hükümetlerin sürdürülebilir mali politikalar, güçlü finansal denetim ve denetleme gibi krizleri önleyebilecek politikalar sürdürmesi üzerindeki baskıları hafifletebilmektedir (Lane ve Phillips, $2001)$. IMF'nin kurtarmaları, daha sonra tekrar benzeri kurtarmaların yapılacağı beklentisine neden olabilmektedir. Bu durum da nasıl olsa yine bir kurtarma olacağı düșüncesi ile hükümet ve yatırımcıların riskli davranıșını teșvik etmekte, kararlarının sorumluluklarına kısmen katlanmalarına ya da hiç katlanmamalarına yol açabilmektedir.

1976'dan 1994'e kadar her seçim döneminde Meksika, sorumsuz para ve maliye politikalarının yol açı̆̆ı bir para krizi yașamıștır. 
Meksika'da yașanan para krizinin ardından her dönem giderek artan miktarlarda ABD Hazinesi ve IMF kurtarmaları gelmiștir. Bu durum Meksika'da bir finansal kurtarma beklentisinin olușmasına yol açmıștır. Meksika'nın kurtarılması, gelișmekte olan ekonomilerde herhangi bir sorun çıkarsa IMF'nin yatırımcıları kurtarmak için gelebileceğine dair bir sinyaldi. Ahlaki riziko, yalnızca 1995 yılında Doğu Asya'ya olan sermaye akıșının neredeyse iki katına çıkmasını açıklamaya yardımcı olmaktadır (Vasquez (2003). Asya'da da borç verenler, finansal sorun olduğu durumlarda hükümet parasının kullanılabileceği bilgisiyle basiretsizce davranmıșlardır.

\section{Meksika Krizi ve Asimetrik Enformasyon}

\subsection{Kriz Süreci}

Büyük sermaye akımları, finansal kurumları zayıflatarak ve finansal bir krize girme olasılığını arttırarak asimetrik enformasyon problemlerini daha kötü bir duruma sokabilir. Dahası, finansal kriz bir kez tetiklendi mi, finansal aracılığa engel olarak, ekonomik faaliyeti yavașlatarak ve iyileșme sürecini yavașlatmak suretiyle asimetrik enformasyon problemleri daha akut bir hale gelebilir (Carstens ve Schwartz, 1998).

90'lı yıllarda gelișmekte olan ülkelere yönelik sermaye akımlarında önemli bir artıș olmuștur. Gelișmiș ülkelerdeki faiz düșüșleri 1990'ların bașlarında Latin Amerika ülkeleri gibi gelișmekte olan piyasalara yönelik sermaye akımlarının nedenleri arasındadır. Sermaye akımları bu piyasalarda ekonomik büyüme ve yatırımlar için gerekli fonu sağlamakla birlikte, bazı istenmeyen sonuçlara da yol açabilmektedir. Sermaye akımlarındaki oynaklıklar, ülkelerin finansal krizlerden etkilenme olasılığını arttırmaktadır.

Meksika'da 80'li yıllarda politik reformlar gerçekleștirilmiștir. Finansal liberalizasyonla birlikte 80 ve $90^{\prime}$ । yılların bașlarında bankacılık sektöründe özelleștirmeler yapılmıștır.

Meksika para politikasının ana unsuru döviz kurlarını nominal çıpa olarak kullanmak olmuștur. Reformların ilk döneminde para birimini dolara sabitlemiș, daha sonra ise daha önceden duyurulan günlük değer düșüklüklerine göre sabitlenmiștir. 1991 yılında ise kurların geniș banda dalgalanmasına izin verilmiștir (Gould ve Gruben, 1995).

Politik reformlar ve küresel piyasalarda faiz oranlarındaki düșüș sayesinde 1990'dan 1994'ün bașlarına kadar Meksika'ya önemli ölçüde sermaye girișleri olmuștur. Meksika ekonomisine yönelik büyük 
ölçekli sermaye akımları, ülke içinde yabancı para cinsinden borç vermede artıșa neden olmuștur. Bu durum, firmaların ve hane halklarının maruz kaldıkları döviz riskinin artmasına yol açmıștır. 1988-1994 yılları arasında özel sektöre verilen banka kredileri GSYiH'nin yüzdesi olarak $\% 13,8$ 'den \%55,2'ye yükselmiștir. Kredilerde yașanan büyük artıșın bir kısmı da ticarete konu olan sektörler dıșındaki alanlara özellikle emlak sektörüne yönlendirilmiștir (Carstens ve Schwartz, 1998). Meksika'ya yönelik sermaye akımları ve rezervlere ilișkin veriler Tablo I'de yer almaktadır:

Tablo I: Meksika'ya Yönelik Sermaye Akımları ve Rezervler (milyar \$, yıllık orandan)

\begin{tabular}{|c|c|c|c|c|c|c|}
\hline $1980-90$ & 1991 & 1992 & 1993 & 1994 & 1995 & 1996 \\
\hline \multicolumn{7}{|c|}{ Net Özel Sermaye Akımları } \\
\hline 1,6 & 20,6 & 23,6 & 30,3 & 10,3 & $-13,2$ & 13,5 \\
\hline \multicolumn{7}{|c|}{ Net Resmi Sermaye Akımları } \\
\hline 2,1 & 2,4 & 2 & $-0,9$ & 0,3 & 24,5 & $-10,0$ \\
\hline \multicolumn{7}{|c|}{ Rezervlerdeki Net Artıș } \\
\hline 0,6 & 8,2 & 1,2 & 6,1 & $-18,9$ & 10,7 & 1,8 \\
\hline
\end{tabular}

Kaynak: Bank for International Settlements (1997). 67th Annual Report. Basle, s. 99.

Gruben ve McComb, (1997)'a göre daha önce baskı alındaki finansal sistem liberalize edildiğinde bankalar yetersiz deneyim, kalifiye eleman ve teknoloji nedeniyle finansal aracılık hizmetlerini verimli bir biçimde yerine getiremezler. Sonuçta finansal aracılık maliyetleri artar. Bankaların portföyleri yeni rejimle artan reel faiz oranları ve kredilerin risklilik durumlarını değerlendiremediklerinden daha riskli bir hale gelir.

Sermaye piyasası liberalizasyonu, gelir, tüketim ve aktif fiyatlarının artmasına neden olan büyük çaplı yabancı sermaye girișine yol açar. Bu aktif balonu, riskli projelere borç vermede bir patlama yaratır. Er ya da geç bu aktif balonu bankacılık sektörü pahasına patlar. Neticede, yabancı yatırımcıları paniğe ve paralarını derhal çekmeye iter. Bunu bankacilık ve ekonomik krizler izler. (Kim ve Lee, 2002).

Meksika'da da özel sektöre yönelik hızla artan krediler, finansal sektörde yetersiz düzenleme ve denetim finansal liberalizasyonla birlikte bankaların așırı risk almalarına yol açmıș; takipteki krediler artmaya bașlamıștır. Uluslararası piyasalarda faiz oranlarının yükselmesiyle sermaye akımlarının azalması, zayıf finansal sistem gibi faktörler yanında 1994'teki kendilerini Zapatista olarak adlandıran isyancıların 
Chiapas isyanı, bașkan adayı Luis Donaldo Colosio'ya yönelik suikast ve Kurumsal Devrim Partisi (Institutional Revolutionary Party) üst düzey sorumlusu Francisco Ruiz Massieu'nun öldürülmesi gibi politik faktörler, Meksika'da belirsizliği finansal kırılganlığı artırmıștır. Mevcut gelișmeler ıșığında yatırımcıların Meksika'ya yönelik beklentileri ve bakıș açıları olumsuz bir hal almıștır. Meksika para birimi pesoya yönelik spekülatif baskılar neticesinde Meksika Merkez Bankası piyasalara müdahale etmek durumunda kalmıștır. Aralık 1994'te peso devalüe edilmiș ve dalgalı kur rejimine geçilmiștir. Devalüasyon, sermaye çıkıșlarını tetiklemiș, enflasyonu arttırmıștır. Yükselen faiz oranları ile geri dönmeyen kredi oranları daha da artmıș, ülkede ekonomik büyüme negatif değerler almıștır. Meksika'da yerli paranın değer yitirmesi yabancı para cinsinden pasiflerin değerini artırmıș ve bu durum firmaların bilançolarında bozulmaya yol açmıș; sonuçta ters seçim ve ahlaki riziko problemlerini artmıștır. Yetersiz kredi analiz tekniklerinin, yetersiz iç denetim mekanizmalarının, yetersiz denetim ve gözetimin olduğu bir ortamda ahlaki riziko problemleri engellenememiș; bașarısız bankaların risklerinin sınırlanmasında yetersiz kalınmıș ve bu durum da finansal incinebilirliğin artmasına yol açmıștır. Asimetrik enformasyon problemleri yabancı yatırımcıların enformasyon elde etmesini güçleștirdiği için fonlarını ülkeden çekmișlerdir. Meksika'ya yönelik porfföy yatırımları yön değiștirmiș; borç vermenin daralması da ekonomik sorunların derinleșmesine yol açmıștır.

\subsection{Meksika Bankacılık Sistemi ve Asimetrik Enformasyon}

1990'ların bașlarında fon elde edilebilirliğindeki hızlı artıș, Meksika'da ticari bankaları pek çok sorunla karșı karșıya bırakmıștır. Bankalar özellikle yeni müșteri temelli kredi geçmișine sahip değillerse yeni borçlular ortaya çıktığında ters seçim problemleri artma eğilimindedir. Meksika'da bankacılık sektörü, hane halkının ve küçük ve orta ölçekli firmaların kredi riskini değerlendirmede enformasyon elde edebileceği etkin kredi bürolarına sahip değildi. Özellikle bankaların faaliyetlerinin artan riskliliğinin maliyetlerine maruz kalmadıkları, yakın geçmiște deregüle edilmiș bir ortamda mevduat sigortasının neden olduğu ahlaki riziko problemleri 1990'lı yılların bașlarında Meksika'da așırı kredi genișlemesinin ardında yatan nedenlerden biridir. Meksika'da mevduat sigortası kuralları uygun bir biçimde olușturulmamıștı; koruma, mevduatın türü ve büyüklüğüne bakılmaksızın tüm banka yükümlülüklerine sunuluyordu (Carstens ve Schwartz, 1998). Diğer bir neden ise, Meksika'da bankacılık sisteminin liberalizasyonu ve özelleștirmesinin sonrasında bankaların rekabetçi ortamda daha fazla pazar payı mücadelesi için 
izledikleri agresif stratejidir (Gruben ve McComb, 1997). 1990'ların bașlarındaki tüketim patlamasının avantajlarından faydalanmak için Meksika'nın finansal kurulușları daha fazla kredi sunmușlardır ancak yanlıș borçlulara. Gelișmekte olan firmaların standartlarına göre, tüketici kredi geçmișlerini raporlama Meksika'da nispeten eksikti ve yeterince organize değildi. Sonuçta geriye dönmeyen krediler artmıștır. Bu faktörler Meksika Bankacılık sistemi üzerine baskı yapmıștır. Sadece 1992'nin son çeyreği ile 1994'ün üçüncü çeyreği arasında geri dönmeyen kredi yüzdesi \%5.6'dan \%8.3'e yükselmiștir (Gruben, 1996). Özellikle ekonominin yükseliș döneminde borçluların risklilik durumları yeterince değerlendirilmeden kredi verilmiștir. Bu borçluların gerçek risk durumları ise ekonomide sorunlar ortaya çıktığında görünür hale gelmiștir.

Tablo II. Meksika'da Toplam Kredilerin Yüzdesi Olarak Geriye Dönmeyen Krediler Durumu (Sadece Ticari Bankalar)

\begin{tabular}{|c|c|c|c|c|c|}
\hline \multicolumn{2}{|c|}{$1980^{\prime}$ lerdeki Krizler } & \multirow{2}{*}{1990} & 1994 & 1995 & 1996 \\
\hline Yıllar & Ortalama & 2.3 & 10.5 & 14.4 & 12.5 \\
\hline 1982 & 4.1 & &
\end{tabular}

Kaynak: Bank for International Settlements (1997), s. 107.

Meksika'daki finansal krizi meydana getiren en önemli faktörlerden biri yurtdıșındaki faiz oranındaki artıștır. Șubat 1994'ten bașında Amerikan Merkez Bankası FED, interbank federal fonlarının oranını arttırmaya bașlamıștır. Bu durum Meksika faiz oranlarında yukarı doğru bir baskı yapmıș ve Meksika finansal sisteminde asimetrik enformasyon problemlerini arttırmıștır. Faiz oranlarındaki artıș, Meksika finansal piyasalarında doğrudan ters seçim problemlerinin artmasına katkıda bulunmuștur çünkü en fazla risk almaya istekli olanların kredi arayanlar olma olasıığını arttırmıștır. Artan faiz ödemeleri hane halklarının ve firmaların nakit akımlarının azalmasına neden olmuș ve bu da onlarının bilançolarının bozulmasına yol açmıștır. Bilançolardaki bozulma, Meksika finansal piyasalarındaki ters seçim ve ahlaki riziko problemlerini arttırmıș ve bu da borç verenlerin borç vermeye daha az istekli olmalarına neden olmuștur (Mishkin, 1996). Meksika Krizi'nin olușumu Șekil 1'de yer almaktadır: 
Șekil 1. Meksika Krizi'nin Olușumu

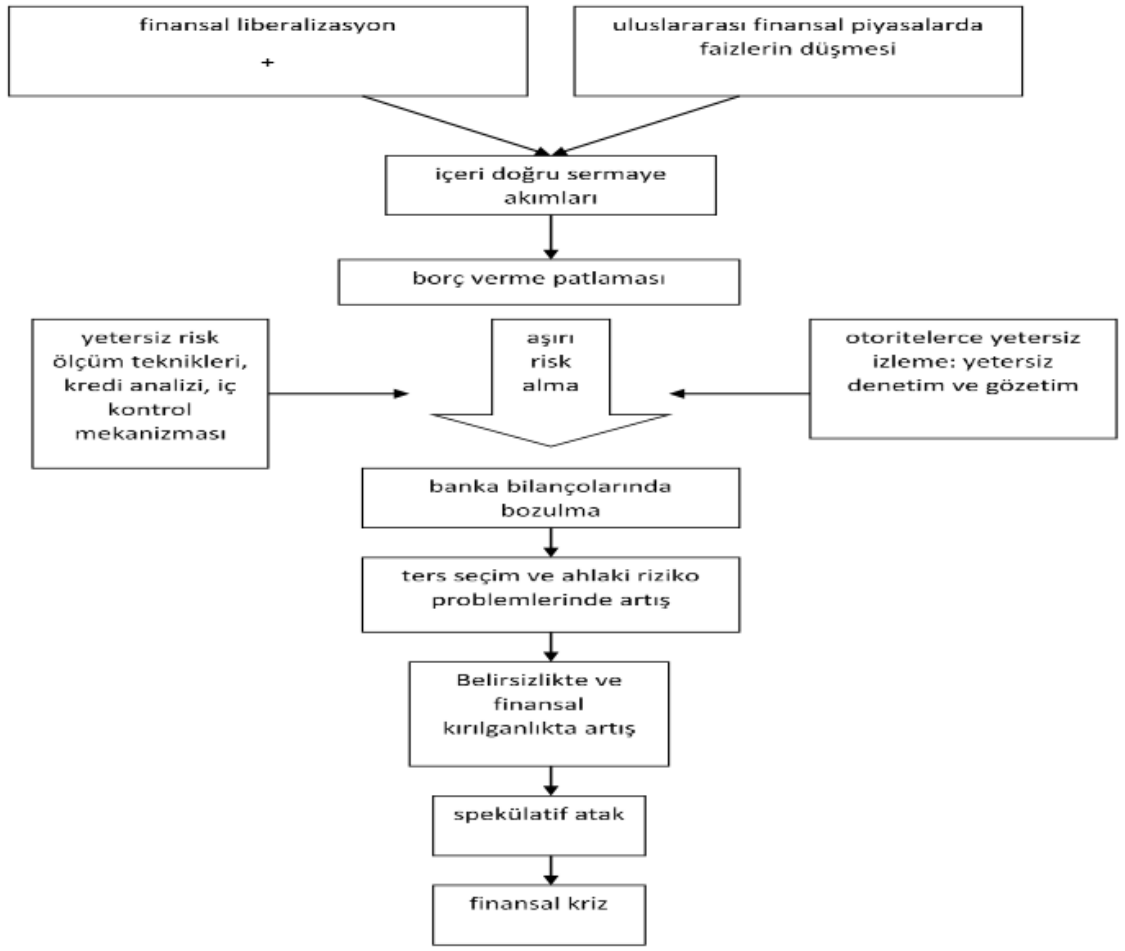

Belirsizlikteki artıș ve hisse senedi piyasasının çöküșünün sonucu olarak net değerdeki azalıș, asimetrik enformasyon problemlerini arttırır çünkü iyi borçluları kötülerinden ayırmak güçleșir. Net değerdeki azalma firmaların teminatlarının değerini düșürür ve daha riskli yatırımlar yapmak için teșviklerini artırır. Bunun nedeni yatırım bașarısız olursa kaybedecekleri daha az özkaynak olmasıdır. Belirsizlikteki artıș ve hisse senedi piyasası çöküșü, faiz oranlarındaki atıșlar ve bankaların bilançolarındaki bozulmalarla birlikte ters seçim ve ahlaki riziko problemlerini kötüleștiren ilk koșullardı ve döviz piyasasında tam bir kriz geliștiğinde Meksika ekonomisini ciddi bir finansal krize hazırlamıștır (Mishkin, 1996). Meksika'da patlak veren para krizinden sonra menkul kıymet piyasası çökmüș; finansal bir kriz gerçekleșmiștir. Kriz yayılma özelliği göstermiș ve bu etki "Tekila Etkisi" olarak adlandırılmıștır. Tekila Etkisi'nin önde gelen hedefleri Arjantin ve Brezilya gibi Latin Amerika ülkeleri olmuștur. Kriz Peru ve Venezuella'da da hissedilmiș ancak tüm Latin Amerika ülkelerine atak olmamıștır. Șili buna örnek gösterilebilir. 
Arjantin ve Meksika bankacılık krizleri yașamıșlardır. Bunun aksine, aynı ticari șoktan etkilenen Șili, bir bankacılık krizinden kurtulmuștur. Șili'deki farklılığı yapan unsur, Șili'nin yatırımın güvenliğinin kanıtlanması ve yeterli sermaye ilkesine göre yurtiçi yatırım projelerine yabancı sermaye tahsisi hakkını sadece belirli bankalara vermesidir. Șili, ayrıca yabancı sermayenin potansiyel para oynaklığı yüzünden ülkeyi terk etmesini de önleyecek șekilde hareket eden bir döviz kontrol sistemi uygulamıștır. (Hickson ve Turner, 1999).

\section{Asya Krizi ve Asimetrik Enformasyon}

Doğu Asya ülkeleri 1990'ların ortalarına kadar oldukça bașarılı bir ekonomik performans çizmișlerdir. Genel olarak bakıldığında Asya ülkeleri (Malezya, Endonezya, Güney Kore, Tayland, Filipinler) görünürde kriz öncesinde yüksek büyüme, tasarruf ve yatırım oranlarına, orta düzeyde enflasyona, düșük bütçe açığı, büyük döviz rezervlerine sahiplerdi. 1997 yazının bașlarında finansal kriz dalgası Asya ülkelerini sarstığında bundan en çok Tayland, Endonezya ve Güney Kore etkilenmiștir. Hong Kong ve Filipinler de krizin etkilerine maruz kalmıștır. Kriz, Temmuz 1997'de para biriminin devalüasyonuyla Tayland'da bașlamıș ve daha sonra bölgedeki diğer ülkelere de sıçrayarak onları da etkilemiștir.

Tayland, șokları yașayan ilk ülkeydi. 97 ilkbaharı boyunca yabancı yatırımcılar sürekli endișeli oldular ve içeri doğru fon akıșı önemli oranda azaldı. Mayıs 1997'de Tayland parası baht yoğun spekülatif baskı alında kaldığında Tayland ilk olarak pariteyi sürdürmek için ne pahasına olursa olsun faiz oranlarını artırdı ve sonuçta maliyet çok arttığında 2 Temmuz'da hükümet, sabit döviz kurunu sürdürme çabalarını terk ederek bahtın dalgalanmasına müsaade etti. İzleyen 6 ay boyunca Tayland para biriminin değeri düșmeye devam etti. Tayland'ın sermaye piyasası da çöktü. Yatırımcının güveni azaldığından, bulașma hızla bölgedeki diğer ülkelere sıçradı. Bir ay içinde Endonezya, Malezya ve Filipinler ard arda para birimlerinin düșmesine izin verdiler, faiz oranlarını artırdılar ve sonrasında bıraktılar. Eylül ayına kadar Singapur, Tayvan ve Hong Kong dolarları da spekülatif baskıdan dolayı teslim oldu. Bölgenin diğer para birimleri büyük bir kriz içine düșmüșken, olağanüstü biçimde Güney Kore wonu Ekim 1997'nin sonlarına kadar görece istikrarlı kaldı. Asya'ya yayılan finansal sıkıntı dalgaları, Temmuz'un bașlarında Endonezya'yı kapladı. Ekim sonuna kadar dolar karșısında Endonezya para birimi rupiahın değeri \%35 düștü. Buna karșılık olarak, dıșardan 
fon akıșları dikkate değer biçimde azaldı, kısa vadeli faiz oranları hızla yükseldi. Ağır finansal yükler alında pek çok yerli ișletme çöktü. Banka ödünç vermesinin hızı kesildi ve geri dönmeyen kredilerin oranı hızla arttı. Bu koșullar altında Endonezya'nın tek kaynağı IMF ve diğer birkaç önde gelen endüstrileșmiș ülkeden yardım istemekti. IMF'nin 10 milyar \$ doğrudan yardım sağladığı anlașma, Ekim'in sonunda hazırlandı (Brimmer, 1998; Puri, Kuan ve Maskooki, 2002).

Güney Kore'de yüksek șirket borç/özsermaye oranı ve büyük miktarda geri dönmeyen banka kredileri, ekonominin önemli yapısal zayıflığını olușturmaktaydı. Bunlar, öncelikle ihracattaki artıșlardan kaynaklanan șirketlerin karlılıkları nedeniyle geçmiște ciddi bir probleme neden olmamıștır, ancak daha sonra önemli bir problem meydana getirdiler çünkü azalan ihracat karlılığı ve yavașlayan ihracat büyümesi dıș borç yükümlülüklerinde ödeme güçlüklerine neden oldu (Kwack, 1998). Kore'de piyasa koșullarının beklediklerinden farklı gelișmesiyle yerli firmaların bir kısmı zor duruma düștü. Firmaların zor duruma düșmesi onlara kredi veren bankalarda da problemlere neden oldu. Firmaların uzun vadede sorunlarının artması ve giderek daha fazla firmanın borçlarını geriye ödeyememesi karșısında bankalar kredilerin bir kısmının kötüleștiğini ve donuk kredilerle dolup taștıklarını anladılar ve dıșardan borçlandıkları kredilerin yükümlülüklerini yerine getirmede zorlandılar. Kore ekonomisinin zor durumda olduğunu anlayan ve diğer Asya ülkelerindeki sorunlarla alarma geçen yabancı borç verenler de kredilerin vadesini uzatmayı reddettiler (Wong, 2000). Bulașmadan etkilenen diğer ülkelerin paraları değer yitirdiğinde artık Güney Kore'nin de pariteyi daha fazla savunabilmesi güçlești. Kia Motor'un iflası büyük ölçekli sermaye çıkıșlarını ve Güney Kore para birimi olan wona atağı teșvik etti. Bu arada Kore Hisse Senedi Fiyat Endeksi (KOSPI)'de 1994'e oranla piyasa kapitalizasyonunun yaklașık \%60'ını yitirdi. (Puri ve diğerleri, 2002).

Güney Kore 3 Aralık'ta 57 milyar \$'lık yardımın onaylandığı IMF ile anlașmaya girdi. Yardım, ekonominin büyüme oranını büyük ölçüde azaltacak çok sayıda sıkı koșullarla geldi. Güney Kore, IMF'den yardım arayana kadar zaten ekonomide çok büyük zarar gerçekleșmiști. Örneğin Aralık'ın sonuna kadar, döviz rezervleri bir yıl öncesinden \%72 düșmüștü. Aynı dönemde wonun dolar karșısındaki değeri \%47 düștü ve hisse senedi fiyatları \%66'nın üzerinde geriledi. Artan sayıda firma iflasları Güney Kore bankaları için ciddi tehdit yaratıyordu. Güney Kore Kasım boyunca dıșarı sermaye çıkıșlarıyla boğuștu. Sonuç olarak ulusla- 
rarası rezerv kaybı ve döviz kurunun düșüșü, yardım için IMF'ye yönelmesine neden oldu (Brimmer, 1998).

Finansal kurumların durumuna bakıldığında Taylan'da finansal kurumların elde ettikleri kısa vadeli fonları uzun vadeli spekülatif yatırımlara uzun vadeli kredi olarak kullandırdıkları görülmektedir. Güney Kore'de de bankalar elde etikleri fonları riskli firmaların spekülatif yatırımlarına aktardıkları görülmektedir. Kullandırılan kredilerin önemli bir kısmı gayrimenkul sektörüne yöneliktir.

Moreno, Pasadilla ve Remolona (1998), krizin köklerinde hızlı büyüme ile maskelenen Asya finansal sistemlerindeki temel zayıflıklar olduğunu, bu zayıflıklara ise bașarısızlığa karșı açık ya da gizli hükümet garantileri tarafından yaratılan etkin risk yönetimi teșvik eksikliğinin neden olduğunu savunmaktadır. Huang ve Xu (1999), Asya'daki finansal krizin temellerdeki kötü uzun vadeli birikmiș problemlerden (Kore bankacılık sistemindeki büyük miktardaki kötü krediler gibi) kaynaklandığını ve bunun yatırımcıların güvenini yok eden, ekonomideki büyük firma/bankaların iflası ile (spekülatif ataklarla birlikte) tetiklendiğini, bu ekonomilerde kötü projelerin durdurulamadığını ve kötü kredilerin biriktiğini; dahası, bankaların kötü projelere kredi vermelerinin daima haklı çıkarıldığını ifade etmektedir. Llevellyn (2002), krize katkıda bulunan faktörler arasında belirgin makro-politika bașarısızlıklara, oynaklığa ve yapısal açıdan zayıf ekonomilere ișaret etmiștir. Bunların yanında Llevellyn, zayıf bankacılık uygulamalarını, bozuk, ahlaksız teșvik yapılarını ve ahlaki rizikoları, zayıf düzenleme ve denetimi de krize katkıda bulunan bașlıca etkenler olarak belirlemiștir. Stiglitz (1999) ise aceleyle ve yetersiz bir șekilde dizayn edilmiș finansal ve sermaye piyasası liberalizasyonunun bu krizlerde merkezi bir rol oynadığına ișaret etmektedir. Krugman (1998), Asya'da yașanan krizde bir büyüme ve patlama döngüsünün varlığından bahsetmektedir: Krugman'a göre krizde sorunlar, aktiflerinin örtülü garanti alında olduğu algılanan fakat aslında regüle edilmemiș ve bu yüzden șiddetli ahlaki riziko problemlerine maruz olan finansal aracılardan bașlamıștır. Bu kurulușların așırı riskli borç vermesi enflasyon yaratmıștır (malların değil fakat aktif fiyatlarının). Bunun sonrasında ise balon patlamıștır; düșen aktif fiyatları onları faaliyetlerini durdurmaya zorlayarak, daha fazla aktif deflasyonuna yol açarak aracıların ödeme acizliklerini görünür kılmıștır.

Asya krizini asimetrik enformasyon görüșü çerçevesinde değerlendiren Mishkin (1999), Doğu Asya krizlerinde, asimetrik enformas- 
yon problemlerinin daha da kötüleșmesine neden olan ve bir finansal kriz bașlatmasındaki ana faktör olarak bilançolardaki, özellikle finansal sektör bilançolarındaki bozulmayı ișaret etmektedir. 1982 Șili ve 199495 Meksika'daki daha önceki finansal krizler gibi, olay, içeriye doğru sermaye akımlarıyla beslenen borç vermede patlamayla sonuçlanan finansal liberalizasyonla bașlamaktadır. Hem faiz oranlarındaki tavanların hem de izin verilen borç verme türü üzerindeki kısıtlamalar bir kez kaldırıldığında borç verme çarpıcı bir șekilde artmaktadır. Asya krizi ülkelerinde kredi genișlemesi GSYIH'dan daha yüksek oranda artmıștır. Borç vermeyle olușan problem, borç vermenin genișlemesi değil, fakat öylesine hızla genișletilmesi ki, bunun sonucunun așırı risk alınmasıdır. Doğu Asya'da finansal liberalizasyonun ardından așırı risk almanın gerçekleșmesinin iki nedeni vardır. Birincisi, bankacılık kurulușlarının yöneticilerinin uygun risk yönetimi uzmanlığından yoksun olmalarıdır. İlave olarak, borç vermede hızlı büyümeyle, bankacılık kurulușları, bu kurulușların bu yeni kredileri uygun bir biçimde ayırma ve izleme olanağı veren iyi eğitilmiș kredi memurları, risk değerlendirme sistemleri gibi gerekli yönetimsel sermayeyi yeterince hızlı ekleyememeleri. İkinci neden, düzenleyici-denetleyici sistemin yetersizliğidir. Bankacılık sistemi için açık devlet güvenlik ağı olmasa bile, ahlaki riziko problemi yaratan örtülü bir güvenlik ağı vardır. Doğu Asya'daki bankaların mevduat sahipleri ve bankalara yabancı borç verenler, muhtemelen onları koruyacak kamu kurtarmalarının olduğunu bilmektedirler. Bu yüzden bankaları izlemek için onlara az teșvik sağlanmıștır ve sonuçta bu kurulușlar așırı risk alma teșvikine sahip olmuștur (Mishkin, 1999).

Düzenleyici kurulușlar ve güvenlik ağlarının yeterince sağlamlaștırılması gerçekleștirilmeden yapılan liberalizasyon, ülkeleri etkisini azaltmak için kötü hazırlandıkları yüksek derecede riske maruz bırakmaktadır (Stiglitz, 1999).

Asya'daki finansal liberalizasyon ve deregülasyon süreci ile birlikte bu ülkelere yönelik sermaye girișleri artmıș; elde edilen fonlar kredi hacminin artmasını sağlamıștır. Krediler verimsiz ve riskli yatırımlara aktarılmıștır. Piyasa disiplinindeki yetersizlikler, yetersiz düzenleme ve denetim mekanizmaları, yetersiz kredi değerlendirme süreçleri neticesinde mevduat sahiplerinin ve denetleyici otoritelerin kredilerin durumu sağlıklı bir șekilde değerlendirilememesine yol açmıștır. Bu durum asimetrik bilgi sorunlarını arttırmıștır. Örtülü garantiler de ahlaki riziko sorunlarının yükselmesine katkıda bulunmuștur. Alınan așırı riskler yabancı para cinsinden kısa vadeli borçlanıp uzun vadeli kredi kullandıran bankaların 
bilançolarını bozmuștur. Bu durum finansal kurulușların kırılganlığını arttırmıștır.

Özellikle Güney Kore'de asimetrik enformasyon problemlerinin krizin olușmasında rol oynadığı görülmektedir. Güney Kore'de bazı firma ve bankalar "batmayacak kadar büyük" olarak kabul edilmiștir; bunun için de örtülü devlet garantileri ile yönetilmișlerdir. Ahlaki riziko ve ters seçim problemlerini teșvik eden hükümetin örtülü kurtarma politikaları, borç patlamasını teșvik etmiș; sunulan krediler kötü ya da verimsiz projelerin finansmanında kullanılmıștır. Asya ülkelerinde toplam kredilerin yüzdesi olarak geriye dönmeyen kredilerin durumu Tablo III'te gösterilmiștir:

Tablo III. Asya Ülkeleri Toplam Kredilerin Yüzdesi Olarak Geriye Dönmeyen Krediler Durumu

\begin{tabular}{|c|c|c|c|c|c|c|}
\hline \multirow[b]{2}{*}{ Ülkeler } & \multicolumn{2}{|c|}{ 1980'lerdeki Krizler } & \multirow{2}{*}{1990} & \multirow{2}{*}{1994} & \multirow{2}{*}{1995} & \multirow{2}{*}{1996} \\
\hline & Yıllar & Ortalama & & & & \\
\hline Hong Kong & & & & 3.4 & 2.8 & 2.7 \\
\hline G. Kore & 1986 & 6.7 & 2.1 & 1.0 & 0.9 & 0.8 \\
\hline Tayvan & 1986 & 5.5 & 1.2 & 2.0 & 3.1 & 3.8 \\
\hline Endonezya & & & 4.5 & 12.0 & 10.4 & 8.8 \\
\hline Malezya & 1988 & 30.5 & 20.4 & 8.1 & 5.5 & 3.9 \\
\hline Tayland & $1983-88$ & 15.0 & 9.7 & 7.5 & 7.7 & Yok \\
\hline
\end{tabular}

Kaynak: Bank for International Settlements (1997), s. 107.

Krugman (1998), yakın dost kapitalizminin de (crony capitalism) Asya krizinde önemli bir rol oynadığını belirtmektedir. Örtülü kamu garantileri ve yetersiz bankacılık denetim ve gözetimi verimsiz kredi tahsisine yol açmıștır. Dost kapitalizmi hakim politik liderlerin devletin olanaklarını, yozlașma ile rant ya da kazançlar sağlayan kendi yakınları ya da dostları lehine kullanmasını ifade etmektedir.

Güney Kore ve diğer Asya ülkelerinde yatırımlarla ilgili asimetrik enformasyona rağmen, yabancı yatırımcılar hükümet tarafından örtülü garanti altında sermayelerini sunmaya hazırlardı. Bu yüzden, dıș yatırımcılar klasik bir ters seçim problemi olan kötü yatırımları iyilerinden ayıramama teșvikine sahiplerdi. Ahlaki riziko teșviki altında, șirketler eğer yatırım bașarısız olursa kaybedecekleri hiçbir șey olmadığından dolayı riskli projelere girișmișlerdir. Yatırımcılar hükümetin kurtarma imkanının olmadığını gördüklerinde, sermayelerini geri çekmeye bașlamıșlardır. Yatırımcılar paralarını çekmek istediklerinde, chaebol de- 
nen șirket gruplarına uzun vadeli kredi veren bankalar kredilerini geriye çağıramamıșlar; yatırımcılar fonlarını çekmek için bankalara, wonlarını dolara çevirmek için döviz piyasalarına hücum etmișlerdir. Paniğe kapılmıș yatırımcıların bir araya gelen eylemleri wonun devalüe edilmesi üzerindeki baskıları artırmıștır. Karsız ya da marjinal olarak karlı cheabol'lere (șirket gruplarına) borç vermekteki ahlaki riziko, geri ödenmeme riskinde artıșa neden olmuștur. Karsız șirketler kötü kredileri geri ödemek ve kısa ve uzun vadeli sermaye gereksinimlerini karșılamak için daha fazla borçlanmıșlardır (Puri ve diğerleri, 2002).

Edwars (1999)'ın saptadığı Meksika ve Asya krizlerine ilișkin incinebilirlik göstergeleri Tablo IV'te, Mishkin'in analizi doğrultusunda Asya Krizi'nin olușumu Șekil 2.'de yer almaktadır:

Tablo IV. İncinebilirlik ve Krizler: Meksika ve Asya

\begin{tabular}{|c|c|c|c|c|c|}
\hline & Büyük Cari Hesap? & $\begin{array}{c}\text { Rijit Nominal } \\
\text { Döviz } \\
\text { Kurları? }\end{array}$ & $\begin{array}{c}\text { Așırı } \\
\text { Değerlenmiș } \\
\text { Döviz } \\
\text { Kurları? } \\
\end{array}$ & Zayıf Bankalar? & $\begin{array}{l}\text { Büyük } \\
\text { Portföy } \\
\text { Akımları? }\end{array}$ \\
\hline $\begin{array}{l}\text { Meksika, } \\
1994\end{array}$ & $\begin{array}{l}\text { Evet, GSYiH'nın } \\
\% 6.5^{\prime} \text { ini așan } \\
(1992-4)\end{array}$ & Evet & Evet & $\begin{array}{l}\text { Evet, geri dön- } \\
\text { meyen krediler } \\
\text { yüksek, zayıf } \\
\text { gözetim ve } \\
\text { denetim } \\
\end{array}$ & Evet \\
\hline $\begin{array}{l}\text { Tayland, } \\
1997\end{array}$ & $\begin{array}{l}\text { Evet, GSYiH'nın } \\
\% 5^{\prime} \text { ini așan } \\
(1995-96)\end{array}$ & Evet & Evet & $\begin{array}{l}\text { Evet, finans } \\
\text { kurumları (finan- } \\
\text { ce houses) çok } \\
\text { zayıf }\end{array}$ & $\begin{array}{l}\text { Evet, BIBF } \\
\text { tarafından } \\
\text { kanalize edi- } \\
\text { len kısa vade- } \\
\text { li akımlar } \\
\end{array}$ \\
\hline $\begin{array}{l}\text { Malezya, } \\
1997\end{array}$ & $\begin{array}{l}\text { Evet, GSYiH'nın } \\
\text { \%6.5'ini așan } \\
(1995-96) \\
\end{array}$ & Evet & Evet & $\begin{array}{l}\text { Evet, zayıf } \\
\text { gözetim ve } \\
\text { denetim }\end{array}$ & Evet \\
\hline $\begin{array}{l}\text { G. Kore, } \\
1997\end{array}$ & $\begin{array}{l}\text { Orta, GSYIH'nın } \\
\text { ortalama \%4'ü } \\
\text { (1996-97) }\end{array}$ & Hayır & Hayır & $\begin{array}{l}\text { Evet, kötü port- } \\
\text { föy çok geniș, } \\
\text { șirket gruplarına } \\
\text { yoğunlașmıș }\end{array}$ & Evet \\
\hline $\begin{array}{l}\text { Endonezya, } \\
1997\end{array}$ & $\begin{array}{l}\text { Ortalama, } \\
\text { GSYiH'nın ortala- } \\
\text { ma \%3.5'i } \\
(1995-96)\end{array}$ & $\begin{array}{l}\text { Evet, sürü- } \\
\text { nen bant }\end{array}$ & Evet & $\begin{array}{l}\text { Evet. Șirket } \\
\text { gruplarının } \\
\text { șüpheli projeleri } \\
\text { finanse edilmiș. }\end{array}$ & Evet \\
\hline $\begin{array}{l}\text { Filipinler, } \\
1997\end{array}$ & $\begin{array}{l}\text { Evet, GSYiH'nın } \\
\% 4^{\prime} \text { '̈nü așan } \\
(1995-96)\end{array}$ & Evet & Evet & Evet & Evet \\
\hline
\end{tabular}

Kaynak: Edwards, S. (1999). On Crisis Prevention: Lessons from Mexico and East Asia. NBER Working Paper Series, No. 7233, s. 42. 
Șekil 2. Mishkin'in Analizi Çerçevesinde Asya Krizi

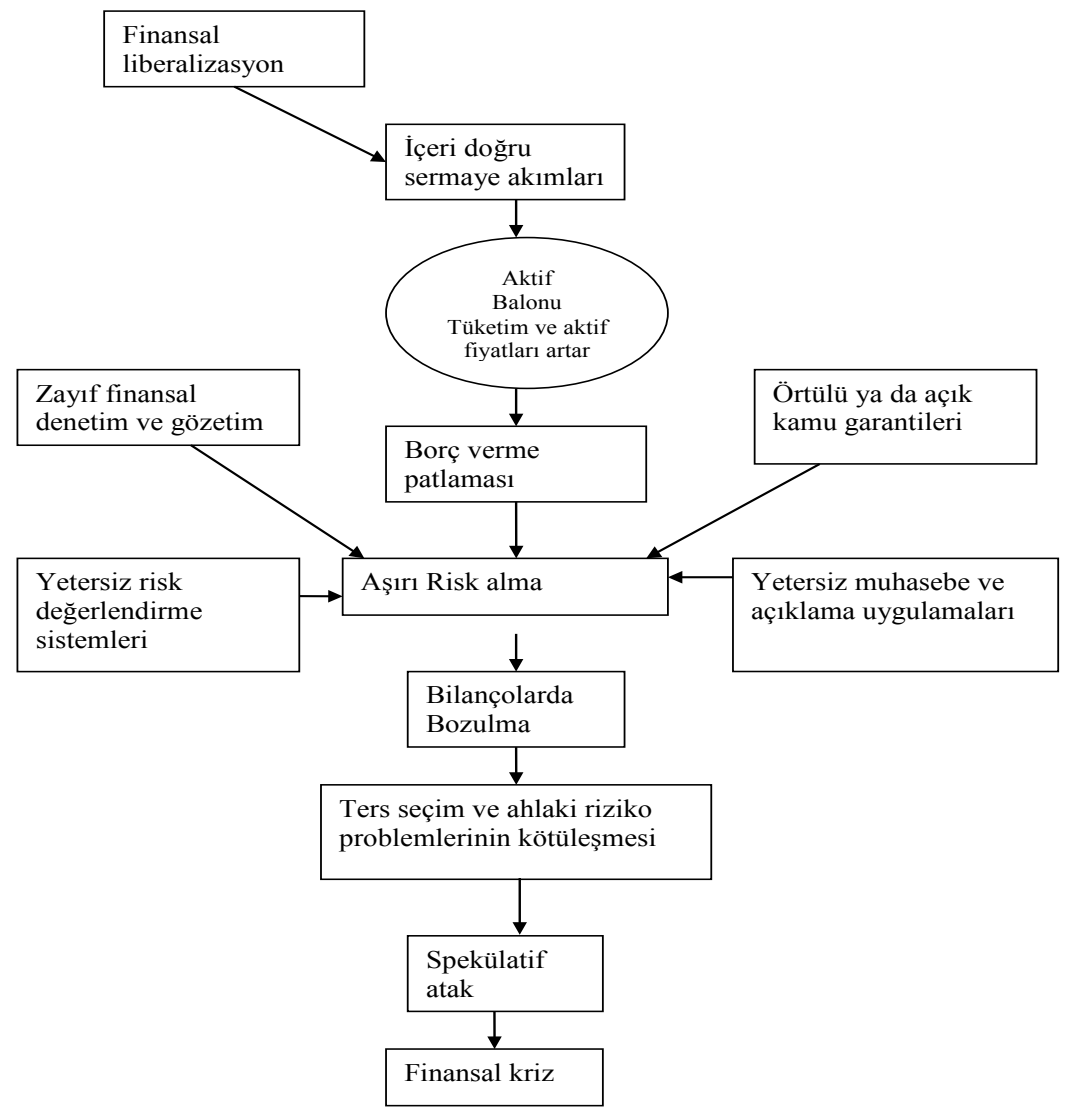

Asya finansal krizi, gelișmekte olan ekonomilerin değișken uluslararası sermaye piyasalarına karșı zayıflığını göstermiștir. Krizden sonra, Asya ülkeleri tarafından krize yol açan zayıflıklarla bașa çıkmak üzere çeșitli önlemler alınmıștır. Her șeyden önce, ilk savunma hattı olarak döviz rezerv birikimi kapsamı genișletilmiș; așırı sermaye akımlarını engellemek için serbest dalgalı döviz kuru sistemine geçilmiștir. Diğer önlemler arasında finansal gözetim ve düzenlemelerin daha etkin hale getirilmesi; ișletmeler, bankalar ve devlet arasındaki bağlantıları kırarak piyasaların ișleyișinin geliștirilmesi ve temel finansal veya kurumsal sektör bilgilerinin ifșası yükümlülüğü getirilerek șeffaflığın arttırılması yer almaktadır (Kim, 2010). 


\section{Sonuç ve Öneriler}

Finansal piyasalarda genellikle taraflar arasında bir enformasyon asimetrisi mevcuttur çünkü borç alanlar yatırımlarının gerçek durumu hakkında borç verenlerden daha fazla enformasyona sahiptir. Asimetrik enformasyonun varlığı fonların verimli projelere aktarıımasını engelleyici bir faktördür.

Kredi piyasalarında ters seçim problemi, kredi verilmesinden önce iyi ve kötü risklilerin birbirinden ayırt edilememesi sorunudur. Ahlaki riziko problemi ise kredi verenlerin kredi alanların faaliyetlerini gözlemleyemediğinde meydana gelmektedir. Finansal piyasalarda ters seçim problemi ișlem öncesinde gerçekleșen bir asimetrik enformasyon problemi iken, ahlaki riziko, borç alanların sözleșme sonrasında borç verenlerin aleyhine olacak șekilde istenmeyen faaliyetlere girișmesi riskidir. Ters seçim ve ahlaki riziko problemleri finansal piyasaların etkin bir șekilde ișleyișine zarar vermektedir.

Firmalar hakkında elde edilebilir enformasyon ne kadar az ise, asimetrik enformasyon problemleri de o denli yoğun olacakır. Özellikle gelișmekte olan ülkelerin yașadığı önemli bir sorun, verimli yatııım projelerine yönelik olarak kaynakların tahsisindeki güçüklerdir. Bu açıdan bakıldığında asimetrik enformasyon problemleri gelișmekte olan ekonomiler açısından daha da önem kazanmaktadır.

Yetersiz denetimin olduğu bir finansal ortamda bankalar ahlaki riziko davranıșı sergileyerek așırı risk alabilirler. Bankacılık sektöründe meydana gelebilecek sorunlar ödemeler sisteminde önemli aksaklıklara yol açabilir ve sadece finansal sektörle sınırlı kalmayıp genel ekonomide de olumsuz etkiler doğurabilir.

Asimetrik enformasyon problemleri finansal krizlerde rol oynayan önemli bir faktördür. Finansal sektördeki șoklar asimetrik enformasyon problemlerinin daha da șiddetlenmesine yol açarak kredi arzının gerilemesine ve yatııımların eksik finansmanına neden olarak harcamaların azalmasına ve ekonomik daralmaya yol açabilmektedir. Asimetrik enformasyon problemleri finansal krizlerin olușumuna katkıda bulunmakta; ayrıca kriz oluștuktan sonra da krizin etkilerinin daha da derinleșmesine ve krizden çıkıș sürecinin uzamasına neden olabilmektedir. Meksika ve Asya krizleri bu duruma örnek verilebilir.

90'l yıllarda genel olarak kriz yașayan Meksika ya da Doğu Asya ülkeleri gibi yükselen piyasa ekonomilerine bakıldığında bu ülkelerin 
kriz öncesi dönemlerde finansal liberalizasyon sürecine girerek yoğun miktarda sermaye akımlarına uğradıkları görülmektedir. Kısa bir sürede içeriye büyük sermaye akımları belirdiği takdirde, finansal sistemde özel izleme ve ihtiyaç tedbirleri alınmalıdır çünkü finansal sistemin istikrarını tehlikeye sokarak asimetrik enformasyon problemleri artabilir. Bir ekonominin, içeriye doğru beklenmedik ve yoğun sermaye akımlarının artan sorunlarıyla bașa çıkabilmesi ve sermaye akımlardan faydalanabilmesi için finansal sağlamlık gereklidir (Carstens ve Schwartz, 1998).

Meksika krizinde ve Doğu Asya krizinde liberalizasyon süreci ve içeri doğru hızla artan sermaye akımları ile așırı kredi genișlemesi, elde edilen fonların riskli, verimsiz alanlara ve ağırlıklı olarak gayrimenkul projelerine yönlendirilmesi durumu söz konusudur. Kredilerde așırı genișleme ile birlikte kredi riskinin değerlemesindeki yetersizlikler neticesinde geriye dönmeyen krediler artmıștır. Kriz deneyimi yașayan ülkelerde genellikle finansal sistemdeki olumsuz teșvik yapılarının ve ahlaki riziko problemlerinin varlığı gözlemlenmektedir. Finansal piyasalara yönelik yasal düzenlemeler yetersiz, gözetim ve denetim mekanizmaları etkin değildir. Bu açıdan bankaların faaliyetlerini izleme ve risklerini doğru bir șekilde değerlendirme asimetrik enformasyon problemlerini gidermede önem kazanmaktadır.

Mevduatlara sağlanan tam güvenceler ya da kamunun sağladığı örtülü garantiler gerek bankaların gerekse mevduat sahiplerinin teșvik yapısını bozarak asimetrik enformasyon sorunlarına yol açabilmektedir. Taraflar, güvencenin varlığı ile daha riskli aktivitelere yönelebilmektedirler. Benzer șekilde uluslararası kurulușlarca sağlanan garanti ve kurtarmalar finansal sıkıntı yașanan ülkelerde karar vericilerin, borç verenlerin ve yatırımcıların teșvik yapısını bozabilmektedir. IMF gibi kurulușlar tarafından sağlanacak kaynakların elde edilebilir olmasının borç veren ve borç alanların riskli davranıșlarını teșvik edebileceği çeșitli kesimlerce savunulmaktadır. Uluslararası kurulușlarca sağlanacak kurtarma paketleri, gelecekte de benzer kurtarmaların yapılacağı beklentisine yol açabilmektedir.

Meksika ve Doğu Asya krizleri değerlendirildiğinde finansal kurumların așırı risk almalarını engellemeye yönelik yasal düzenlemelerin hayata geçirilmesi; finansal kurumlara yönelik etkin gözetim ve denetim yapılarının olușturularak bankaların etkin bir șekilde izlenmesi, kredi müșterileri hakkında enformasyon sağlayıcı kredi büroları gibi kurumların hayata geçirilmesi önem tașımaktadır. 
Enformasyon problemlerinin önüne geçilebilmesi için daha fazla enformasyon üretilmesi ve bunların taraflara zamanında, doğru bir șekilde aktarılmasını sağlayacak mekanizmalar olușturulması gereklidir. Bankaların ahlaki riziko davranıșlarını sınırlandırabilmek için hem daha az risk almayı teșvik edecek düzenlemelerin yapılması hem de bankaların bu düzenlemelere uyup uymadıklarını anlamak için etkin bir șekilde izlenmeleri gereklidir. Etkin bir denetim ve gözetim sistemi ile uygun düzeyde sermaye yeterlilik oranlarının saptanması ve uygulanması; uygun teșvik mekanizmalarının sağlanması, piyasalarda șeffaflığın artırılmasına yönelik çalıșmaların yapılması ile asimetrik enformasyon problemlerini azaltmak mümkündür.

\section{Kaynakça}

Bank for International Settlements (1997). 67th Annual Report. Basle.

Bems, R. \& Jönsson, K. (2002). Bank Crises in Emerging Markets and the Optimal Government Bailout Policy. SSE/EFI Working Paper Series in Economics and Finance, No. 520.

Bordo, M. D. \& Murshid, A. P. (2000). Are Financial Crises Becoming Increasingly More Contagious? What Is The Historical Evidence On Contagion? NBER Working Paper Series, No. 7900, Cambridge, MA: National Bureau of Economic Research.

Brimmer, A. F. (1998). Bank Lending and the Asian Economic Crisis. North American Journal of Economics \& Finance, Vol. 9, Issue 1.

Bustelo, P., Garcia, C. \& Olivie, I. (1999). Global and Domestic Factors of Financial Crises in Emerging Economies: Lessons from the East Asian Episodes (1997-1999). Instituto Complutense De Estudios Internacionales Universidad Compultense De Madrid, Madrid: Spain, Iceı Working Paper, No. 16.

Caprio Jr., G. (1998). Banking on Crises: Expensive Lessons from Recent Financial Crises. World Bank, Washington DC.

Caprio Jr., G. \& Klingebiel, D. (1996). Bank Insolvency: Bad Luck, Bad Policy, or Bad Banking? Annual World Bank Conference on Development Economics, World Bank, Washington DC.

Carstens, A. \& Schwartz, M. J. (1998). Capital Flows and the Financial Crisis in Mexico, Journal of Asian Economics, Vol. 9, No. 2.

Demirgüç-Kunt, A. \& Detragiache, E. (1997). The Determinants of Banking Crises: Evidence from Developed and Developing Countries. Policy Research Working Paper, No. 1828, World Bank, Washington DC.

Edwards, S. (1999). On Crisis Prevention: Lessons from Mexico and East Asia. NBER Working Paper Series, No. 7233. 
Eichengreen, B. \& Bordo, M. D. (2002). Crises Now and Then: What Lessons from the Last Era of Financial Globalization. NBER Working Paper Series, No. 8716, Cambridge, MA: National Bureau of Economic Research.

Gould, D. M. \& Gruben, W. C. (1995). The Roots of Mexico's Peso Crisis. Federal Reserve Bank of Dallas, Southwest Economy, Issue 1.

Gruben, W. C. (1996). Policy Priorities and the Mexican Exchange Rate Crisis. Federal Reserve Bank of Dallas, Economic Review, First Quarter.

Gruben, W. C. \& Robert McComb, R. (1997). Liberalization, Privatization, And Crash: Mexico's Banking System in the 1990s. Federal Reserve Bank of Dallas, Economic Review, First Quarter.

Hahm, J. H. \& Mishkin, F. S. (2000). The Korean Financial Crisis: An Asymmetric Information Perspective. Emerging Markets Review, Vol. 1.

Heffernan, S. (1996). Modern Banking in Theory and Practice. England: John Wiley \& Sons.

Hermalin, B. E. \& Rose, A. K. (1999). Risks to Lenders and Borrowers in International Capital Markets. NBER Working Paper Series, No. 6886, Cambridge, MA: National Bureau of Economic Research.

Hickson, C. R. \& Turner, J. D. (1999). Banking Instability in South East Asia: Causes and Cures. European Business Review, Vol. 99, No. 3.

Huang, H. \& Xu, C. (1999). East Asia: Miracle or Bubble? - Financial Institutions and the Financial Crisis in East Asia. European Economic Review, Vol. 43.

IMF (1998a). World Economic Outlook. International Monetary Fund, Washington DC.

IMF (1998b). The Asian Crisis, Causes and Cures. Finance \& Development, International Monetary Fund, Washington DC.

Kale, S. \& Eken, M. H. (2017) . "Türk Bankacılığında Krizler ve Çıkarılan Dersler". Kırklareli Üniversitesi İktisadi ve İdari Bilimler Fakültesi Dergisi 6 / 5 11-23.

Karadağ, M. M. \& Selimler, H. (2014). "Kredi Değerlendirme Sürecinde Asimetrik Bilgiyi Azaltmaya Yönelik Uygulamalar, Tespit Ve Öneriler". Maliye Finans Yazıları, 27(101), 87-124.

Kirabaeva, K. (2010). Adverse Selection and Financial Crises. Bank of Canada Review, 11.

Kim, C. (2010). Financial crises and policy responses - a Korean perspective. Speech at the Bank of Japan's annual Tripartite Governors' Meeting, Tokyo, 3 August 2010. BIS Review 104/2010.

Kim, Y. J. \& Lee, J. W. (2002). Overinverstment, Collateral Lending, and Economic Crises. Japan and the World Economy, Vol. 14.

Koh, H. L. , The, S. Y. \& Tan, W. K. (2016). Global Financial Crises: Origin and Management. International Journal of Economics and Financial Issues, 6 (3S), 92-98.

Krugman, P. (1998). What Happened to Asia. http://web.mit.edu/krugman/www/ DISINTER.html. 
Kwack, S. Y. (1998). Factors Contributing to the Financial Crisis in Korea. Journal of Asian Economics, Vol. 9, No. 4.

Lane, T. \& Phillips, S. (2001). IMF Financing and Moral Hazard. Finance \& Development, Vol. 38, No. 2, International Monetary Fund, Washington DC.

Lee, S. J., Posenau, K. E. \& Stebunovs V. (2017). The Anatomy of Financial Vulnerabilities and Crises. Board of Governors of the Federal Reserve System. International Finance Discussion Papers 1191.

Llevellyn, D. T. (2002). An Analysis of the Causes of Recent Banking Crises. The European Journal of Finance, Vol. 8.

Ma, Z. \& Cheng, L. K. (2003). The Effects of Financial Crises on International Trade. NBER Working Paper Series, No. 10172, Cambridge, MA: National Bureau of Economic Research.

Mishkin, F. S. (1990). Anatomy of a Financial Crisis. NBER Working Paper Series, No. 3934, Cambridge, MA: National Bureau of Economic Research.

Mishkin, F. S. (1996). Understanding Financial Crises: A Developing Country Perspective. NBER Working Paper Series, No. 500, Cambridge, MA: National Bureau of Economic Research.

Mishkin, F. S. (1999). Lessons from the Asian crisis. Journal of International Money and Finance, Vol. 18.

Mishkin, F. S. (2000). Prudential Supervision - Why Is It Important and What Are The Issues? NBER Working Paper Series, No. 7926. Cambridge, MA: National Bureau of Economic Research.

Mishkin, F. S. (2001a). Financial Policies and The Prevention of Financial Crises in Emerging Market Countries. Policy Research Working Paper, No. 2683, World Bank.

Mishkin, F. S. (2001 b). The Economics of Money, Banking and Financial Markets. Sixth Edition, USA: Addison Wesley.

Mishkin, F. S. \& Strahan, P. (1999). What Will Technology Do to Financial Structure? Brookings-Wharton Papers on Financial Services.

Moreno, R., Pasadilla, G. \& Remolona, E. (1998). Asia's Financial Crisis: Lessons and Policy Responses. Pacific Basin Working Paper Series, No. PB98-02, Center for Pacific Basin Monetary and Economic Studies, Economic Research Department, Federal Reserve Bank of San Francisco.

Puri, T. N., Kuan, C. \& Maskooki, K. (2002). An Analysis of Currency Crisis in South Korea. Global Finance Journal, Vol. 13, 2002.

Stiglitz, J. E. (1999). Lessons from East Asia. Journal of Policy Modeling, 21 (3).

Stiglitz, J. E. \& Weiss, A. (1981). Credit Rationing in Markets With Imperfect Information. The American Economic Review, Vol. 71.

Stulz, R. M. (1999). Globalization of Equity Markets and the Cost of Capital. NBER Working Paper Series, No. 7021, Cambridge, MA: National Bureau of Economic Research.

Yay, T., Yay, G. \& Yılmaz, E. (2001). Küreselleșme Sürecinde Finansal Krizler ve Finansal Düzenlemeler. İstanbul: İstanbul Ticaret Odası Yayını, No. 2001-47. 
Vasquez, I. (2003). International Financial Crises and the IMF. Cato Handbook for Congress: Policy Recommendations for the 108th Congress, https://object.cato. org/sites/cato.org/files/serials/files/cato-handbook-policymakers/2003/9/ hb108-64.pdf.

Wong, K. Y. (2000). Firm Failure and Financial Crisis: The Experience of South Korea. The Journal of the Korean Economy, Vol. 1, No. 1. 